Accepted Manuscript (AM) of Vullnetari, J. and King, R. (2011) 'Washing men's feet': Gender, care and migration in Albania during and after communism. Gender and Development 19(1): 39-51 [DOI:

10.1080/13552074.2011.554020][accepted November 2010; first published online 17 March 2011].

\title{
Gendering remittances in Albania: a human and social development perspective
}

\section{Julie Vullnetari and Russell King}

Gender issues are of central importance to both migration and development. The study of migrant remittances has been at the heart of the fast-growing literature on migration and development. And yet, surprisingly, remittances and gender issues have rarely been brought together as a subject of inquiry. Based on recent research in south-east Albania and in the Greek city Thessaloniki, our paper aims to address this gap. We do this in three ways. First, we examine who sends, who receives, and who uses remittances, from a gender perspective. Second, we go beyond looking at financial transfers, to consider non-monetary remittances. Third, we analyse how gender relations and gendered social norms shape migration and remitting patterns; and how these, in turn, affect gender relations in migrant households and in origin communities. Although the unit of analysis is the transnational household, spanning rural Albania and urban Greece, the different experiences of individual migrant women and men are central. These perspectives in turn inform recommendations for researchers, policy-makers and practitioners.

Key words: gender, remittances, human development, Albania

[The Version of Record of this manuscript has been published and is available in Gender and Development; 17 March 2011; DOI: 10.1080/13552074.2011.554020]. 
Accepted Manuscript (AM) of Vullnetari, J. and King, R. (2011) 'Washing men's feet': Gender, care and migration in Albania during and after communism. Gender and Development 19(1): 39-51 [DOI:

10.1080/13552074.2011.554020][accepted November 2010; first published online 17 March 2011].

\section{Introduction}

The debate on how migration and development impact on one another has been going on for some decades now. Remittances - the money that migrants send to their families and relatives in areas of origin - have been at the heart of these discussions. However, we still know very little of how the remitting process is gendered, and how that, in turn, affects development. This neglect is all the more surprising, since gender has been a key analytical tool in the vast and growing research literatures on both migration and development.

This article aims to shed light on the remittance aspect of the migration-development relationship, through a gendered analysis of transnational households in the context of Albanian migration to Greece. The article is based on data collected for a project funded by the United Nations International Research and Training Institute for the Advancement of Women (UN-INSTRAW), carried out during 2007-09. The research tools comprised a survey of 350 remittance-receiving households in rural south-east Albania; 45 in-depth interviews with some of these families, as well as with migrant women and men in the Greek city of Thessaloniki; and in-depth interviews and roundtable discussions with key stakeholders in both countries.

First, we provide a brief theoretical discussion of the key concepts around which this paper is built - namely, human development and gendered remittances. This is followed by an introduction to our research context in Albania. We then analyse our findings, focusing on three aspects in particular: the senders and receivers of migrant remittances; the uses to which the money is put; and the interplay between gender issues and remittances. We conclude the article with a number of recommendations for researchers, policy-makers and practitioners.

\section{Gendered remittances and human development: a brief conceptual frame}

In this article, we use the two concepts of human development and gendered remittances to help us in our analysis. We focus specifically on the gendered impacts of migration and remittances as potential avenues for the individual development of migrant men and women 
Accepted Manuscript (AM) of Vullnetari, J. and King, R. (2011) 'Washing men's feet': Gender, care and migration in Albania during and after communism. Gender and Development 19(1): 39-51 [DOI:

10.1080/13552074.2011.554020][accepted November 2010; first published online 17 March 2011].

and their family members. A more egalitarian family, in turn, can contribute to a more egalitarian community and society.

In the migration studies literature on development, and certainly in that part which examines remittances, development is most often considered from a narrow economic perspective of income growth and business investment. In this paper we understand development to mean human development as conceptualised by Amartya Sen (1999) and advanced in migration studies by Hein de Haas (2009). This approach emphasises the importance of people's quality of life, and focuses on the expansion of choices. This perspective has become key to many studies of development, and was at the heart of the 2009 Human Development Report (HDR) which focused for the first time on migration as an avenue to human development (UNDP 2009). The effects of migration are not always positive, but they can potentially expand people's capabilities to lead lives they have reason to value, which includes giving them more choices. This process in turn can also potentially bring about wider economic progress.

Of course, migration is not only important for its economic effect on the livelihoods of migrants and their families, but for its social, cultural, and political impact also. All of these non-economic factors have an impact on women and men, and gender relations.

This article focuses on these concerns by analysing the issue of migrant remittances from a gender perspective. Until recently, the study of gender and remittances has been marginal within the broader debates which have taken place about migration, gender and development. The majority of studies which have considered gender issues when analysing remittances have tended to revolve around the question of whether women are better remitters than men (King and Vullnetari 2010). The evidence on this question is quite mixed and inconclusive (Vullnetari and King 2011).

To reach a deeper understanding of migrant remittances from a gender perspective, what is needed is: 
- a transnational perspective, which considers remittances as an activity which takes place across national borders, and is embedded in social and kinship relations that stretch between migrants' communities of origin and destination;

- a gendered approach which considers gendered power relations (Mahler and Pessar 2001) in both origin and host societies, and how such relations change through migration and remittances;

- methodologically a multi-sited ethnographic approach to studying remittances (following Marcus 1995), taking the transnational household as the unit of analysis. This means that ethnographic research needs to take place in multiple sites, which include both the areas of origin of migrants and the places in destination countries where they have settled;

- a conceptual extension of remittances to include non-monetary transfers such as social, technological and in-kind remittances. By this, we mean ideas, practices, technological knowledge as well as clothes, furniture, medicine, machinery etc. which are sent from migrants to their families and communities of origin. Some of these have been noted by other researchers such as Levitt (1998) and Goldring (2003).

This article aims to adopt this perspective. In the next section we provide a brief snapshot of Albania, the migrants' country of origin where we conducted part of our research.

\section{Albania: a contextual snapshot}

Albania was, until the beginning of the 1990s, the most isolated state of the former socialist bloc in Europe. During nearly half a century of communist rule (1945-1990), emigration was banned and there was a shoot-to-kill policy for those who tried to escape. As the regime collapsed in the early 1990s, so too did the borders - at least on the Albanian side. By 2010, more than a third of the country's population had emigrated and was living abroad, primarily in Greece $(600,000)$ and Italy $(450,000)$.

The first migrants to leave Albania were mostly men. There were a number of reasons for this. First, the highly patriarchal character of Albanian society privileged younger men as migrants; the migration of young single women for work is still frowned upon, especially in 
Accepted Manuscript (AM) of Vullnetari, J. and King, R. (2011) 'Washing men's feet': Gender, care and migration in Albania during and after communism. Gender and Development 19(1): 39-51 [DOI:

10.1080/13552074.2011.554020][accepted November 2010; first published online 17 March 2011].

rural areas. Second, the migratory journey - over the snowy mountains to reach Greece, or by small rubber boats to enter southern Italy during the night - was seen as dangerous and this further discouraged women from going and men from 'letting' women to go. Thirdly, the work opportunities in these host countries - mostly in construction and agriculture and the migratory life of those early years - sleeping mostly in barns and outside in the fields - likewise tended to be 'off-limits' to women. Some women did take part in these early migrations, but the majority joined their male family members later, in the late 1990 s and early 2000s, following the large-scale regularisation schemes for migrants in Greece and Italy. The vast majority of Albanian women in Greece and Italy work in domestic and care services. Even when they have a regular staying permit, they often work informally, mostly because their (often female) employers are not willing to pay the extra cost of employers' contributions such as social insurance. At times the requirements for family reunification are very difficult to meet and the women may join their husbands clandestinely. This in turn means their irregular stay and unauthorised employment may put them in a precarious position and make them more dependent on their male family members.

Nowadays, many of these migrants have settled permanently in Greece and Italy, although some return migration has taken place. This is primarily of those who have not been able to regularise their stay in these host countries, but also to some extent of those who have returned for family and personal reasons, or to start a small business with the savings from abroad. Return migration is seriously under-researched in the Albanian context, especially as numbers were presumed to be small until very recently. Some of those who returned to rural areas have continued to migrate seasonally, working mainly in agriculture in Greece. Transnational activities are particularly intensive among communities living in close geographical proximity to the Albanian-Greek border - both in south-eastern Albania and on the Greek side up to the city of Thessaloniki, which were also the locations where our research took place. These transnational activities include visits from migrants to their families in the villages several times a year or visits in the opposite direction (when enabled by visas and staying permits), sending remittances back to Albania, as well as trans-border business activities. Partly because of this geographical proximity, most of our survey participants received remittance money from their migrant relatives informally; that is, 
Accepted Manuscript (AM) of Vullnetari, J. and King, R. (2011) 'Washing men's feet': Gender, care and migration in Albania during and after communism. Gender and Development 19(1): 39-51 [DOI:

10.1080/13552074.2011.554020][accepted November 2010; first published online 17 March 2011].

when the latter came to visit, they brought the money with them, or sent it via friends, relatives and, less often, paid couriers. Relatively little use was made of formal remittance channels, such as banks or money-transfer companies.

In the rest of the article, we will go into more detail on the gendered dynamics of the remittance process.

\section{Sending and receiving financial remittances}

According to Albanian tradition, which follows the male line of inheritance, a woman moves into the house of her husband upon marriage. Here, the young couple lives with the husband's parents and any unmarried siblings. The youngest son and his wife have the responsibility of looking after the son's parents in old age, whereby the wife will often provide the care services they may need. The parents of the wife are looked after by her youngest brother and his spouse. When a couple has no sons, daughters and sons-in-law take over these duties.

Our research findings suggest that remitting money is a process which is very much shaped by both gender and generation. In our research, we defined the households we came across as either 'female-headed' or 'male-headed' depending on the sex of the person (in Greece) who sent or (in Albania) who administered the remittances. We now discuss both these types of household in the remittance-receiving and remittance-sending contexts.

\section{Remittance-receiving households}

Female-headed households are nuclear households in which the husband has migrated long-term or seasonally to Greece, while the wife and the couple's children live in the village in Albania. In such households, the wives receive and administrate remittances sent by their migrating husbands. This type makes up 20 per cent of the total households in our study. Another type of female-headed household consists of the migrant's wife and children, and his elderly parents who are often ill and in need of care. Once again it is the migrant's wife who administers remittances. The share of such households in the total survey was lower, at 
Accepted Manuscript (AM) of Vullnetari, J. and King, R. (2011) 'Washing men's feet': Gender, care and migration in Albania during and after communism. Gender and Development 19(1): 39-51 [DOI:

10.1080/13552074.2011.554020][accepted November 2010; first published online 17 March 2011].

around 8 per cent. A third type -7 per cent of the total households - is that headed by widows who live alone, or look after grandchildren of migrant sons and (less often) daughters. The youngest son - where there is one - is responsible for looking after his mother so he sends remittances to her. If the widow is looking after grandchildren of her daughter, the latter may send some remittances too.

In some households where women live with their children in the village, the husband's elderly parents are also present. We defined these households as male-headed if it is not the wife, but the father of the emigrant, who administrates the remittances. They make up 7 per cent of the total households in our study. A second type of male-headed household is one in which the migrant's parents and siblings live in the village, while the migrant son is single. Remittances are sent from the son and administered by the father. They make up 13 per cent of the total households in our study. A third type is one in which the migrant's parents live on their own in the village, while all their adult migrant children with their spouses and the grandchildren have migrated - either abroad or internally in Albania. They make up about 4 per cent of the total.

It is important to note that almost no households in our Albania study contained stay-athome husbands who are receiving remittances from their migrant wives.

\section{Remittance-sending households}

There are three main types of household in which migrants live in Greece: nuclear households, where a migrant couple live with their young children (and sometimes a relative, usually the brother of the husband) - the most numerous by far in our research; nuclear households, where the migrant couple is joined by the elderly parents of the man; and men who share a household with other men, either because they are single, or because they have emigrated alone and their wives and children remain in the village.

Single men are amongst the most important remittance-senders in terms of volume of remittances, as are married men whose family lives in the village. When the nuclear migrant couple lives together in Greece, remittances to Albania - sent mainly to their parents and 
Accepted Manuscript (AM) of Vullnetari, J. and King, R. (2011) 'Washing men's feet': Gender, care and migration in Albania during and after communism. Gender and Development 19(1): 39-51 [DOI:

10.1080/13552074.2011.554020][accepted November 2010; first published online 17 March 2011].

siblings - decrease significantly, since it is generally accepted that their primary responsibility is to sustain their own nuclear families in Greece.

\section{Complexity and change}

The channels through which remittances are sent from Greece to Albania are strongly shaped by gender and generational relations within the context of Albanian cultural norms. Thus, almost all the respondents in the household survey reported that men were the principal senders of remittances; only in four cases (out of 350) were these women. About 40 percent of all respondents reported one or more additional remittance senders; of these nearly half were the spouses of the principal remitter. Because the questions in the quantitative survey focused on the households in the villages and the principal remitter, we did not collect systematic data about other remitters, including spouses. However, through our in-depth interviews and informal conversations with those who participated in the research we can say that migrant women worked primarily in domestic cleaning and caring; some worked in the hotel and restaurant sector, in agriculture and manufacturing; and some worked at home looking after the children and the household.

However, this fairly homogenous picture of men as remitters was generated partly because the questionnaire asked information on the principal remittance-sender. During in-depth interviewing and field observations we were able to gather additional data which reveal a more heterogeneous and complex view. While women may not be the 'principal' remitters, they do remit in various ways. Yet, these remittances are considered - by the recipient families and the migrants themselves - as less important than those sent by men. This is reflected also in the way they are labelled: 'official' remittances (from men) are labelled as 'support', 'wages' and 'pensions' - the last of these when sent to elderly parents; whereas 'non-official' ones (mainly from women) are considered as 'gifts', 'presents', or 'just for a coffee' (see also Smith 2009).

However, gendered patterns of remitting and receiving are not static, and change does occur - albeit slowly. This is partly as a result of migration, and partly as a result of the exigencies 
Accepted Manuscript (AM) of Vullnetari, J. and King, R. (2011) 'Washing men's feet': Gender, care and migration in Albania during and after communism. Gender and Development 19(1): 39-51 [DOI:

10.1080/13552074.2011.554020][accepted November 2010; first published online 17 March 2011].

of life in Albania and abroad. The following example helps to tease out the complexity of these gendered remitting patterns and channels.

Anila (1), aged 25, lives as a migrant in Thessaloniki with her husband (aged 28), their twoyear-old son, and her husband's younger brother, aged 20. Both Anila's husband and her brother-in-law work in construction, whereas Anila herself works at home looking after the couple's young son, and taking care of the household chores such as cooking and cleaning for the family. Anila's parents and in-laws all live in south-east Albania. Anila's brother-inlaw has the responsibility of looking after his parents, as the youngest brother. As such, the money he earns in Greece is sent regularly to them. Anila's husband also gives some money to his parents. This is around $€ 100-€ 200$, handed over when Anila and her husband go to visit every few months. Anila's father-in-law receives the money from his sons - an example of a 'male remitting channel' (King et al. 2006). Given Anila's husband's rank in the line of sons (that is, he is not the youngest), the money he gives his parents is considered as a gift given out of respect (when Anila was telling us about this, she used the Greek word dhoro), since there are no social expectations that he should send his parents regular support money.

Anila and her husband also remit to her parents - she gives the money to her mother when she visits Albania. We can see this as a 'female remitting channel'. Since Anila is a daughter, remittances are not expected from her either, and the money is 'just for a coffee' - that is, a symbolic present of respect. It is her youngest brother who has the responsibility of looking after the parents and maintaining the household. He is not married yet, and sends regular remittances from the Greek island of Crete, where he has been working for many years.

When she cannot travel to Albania, Anila sends money for her parents via her sister-in-law, who also works and lives with her own family in Thessaloniki. Although sisters-in-law are not traditional allies in the Albanian family context, the practicalities of life abroad affect these relationships to some extent. The sister-in-law collects two amounts of money from Anila to take back to Albania. The first of these is the sum which the young couple will send to Anila's parents-in-law. This is pooled with the money the sister-in-law will give them, and 
Accepted Manuscript (AM) of Vullnetari, J. and King, R. (2011) 'Washing men's feet': Gender, care and migration in Albania during and after communism. Gender and Development 19(1): 39-51 [DOI:

10.1080/13552074.2011.554020][accepted November 2010; first published online 17 March 2011].

handed over to Anila's father-in-law. The remitting channel this time is mixed-sex, from female to male. The second sum of money which Anila gives to her sister-in-law to take on her behalf is destined for Anila's family, and this is handed over to Anila's mother - a female remitting channel once again. Anila explains that because her husband is away at work all day, it is only practical that she hands the money over to her sister-in-law when the latter travels to Albania.

That Anila does not have paid employment has certain implications for the money that is remitted. During our interview with her she said that her husband had not left her parents aside and had treated them well. This illustrates the point that because the husband is the person earning the money in the household, he is the stronger individual within the nuclear family when it comes to power relations and remitting. However, as other research has found, at times even when migrant women work, all earnings are pooled together and administered by the husband, who in turn decides where and how much to remit (King et al. 2006).

Of course, gender relations are quite heterogeneous even within the same country. In our case, the rural origin of our informants - who could be expected to have more traditional and conservative perspectives on gender relations - is softened somewhat by the fact that they come from the south-east of Albania, a region which has more egalitarian gender relations than the North of the country, mainly as a result of the impact of pre-1945 migrations.(2)

\section{Using remittances to enhance capabilities}

The ways in which migrants' remittances can be used is at the heart of the debate on whether remittances expand the capabilities of migrants and their families. As mentioned earlier, often such debates revolve around the way remittances are used in narrow economic terms. That is, unless invested in 'productive' enterprises, remittances are not considered positive for the receiving community and country. Often, such evaluations of what is productive and what is not are made by policy-makers based in the global north, who do not 
Accepted Manuscript (AM) of Vullnetari, J. and King, R. (2011) 'Washing men's feet': Gender, care and migration in Albania during and after communism. Gender and Development 19(1): 39-51 [DOI:

10.1080/13552074.2011.554020][accepted November 2010; first published online 17 March 2011].

consider development issues from the perspectives of migrants, the poor, or local practitioners on the ground.

Applying the concept of capabilities, we find that migration and remittances can potentially expand women's and men's abilities to take control over their own lives. Amongst our respondents, there was a high degree of using remittances to increase the quality of life of families in terms of health and education. For example, money sent by fathers had enabled children's education to continue beyond compulsory level (nine years of schooling). There were gendered implications here too. Interestingly, it was daughters, in particular, who continued secondary and higher education, while sons tended not to regard school as adding value to their future life in Albania, and chose to follow their fathers abroad instead. Such pessimistic outlooks were due to the situation in rural areas and Albania more generally, where the education system does not fit the requirements of the labour market, and where young graduates are often unemployed or under-employed. Indeed, a number of highlyeducated young women we came across during our research in the villages were unemployed, and did not have much hope that their situation would improve in the near future. However, we also found that higher education did increase some women's chances of making a better marriage, considered as such when the husband was a settled migrant with regular papers, especially if living in North America, or when his family was affluent. Young men - who are expected to be the breadwinners when they create their own family considered that emigration was more immediately rewarding for them than education.

Some money was used to further people's social status, in ways which some commentators would see as 'irrational', or condemn as 'conspicuous consumption'. More than 80 per cent of our survey respondents reported that they used remittances to sustain their social status in the surrounding community. Investments of these kinds are very important: they enable people to participate 'honourably' in life-cycle events such as births, weddings, funerals, baptisms, and other activities, and these events often act as social markers in communities and kinships. Not being able to participate in, or host, such activities, means social isolation. We illustrate this point with a quote from a 47-year-old woman in a village, who sees the 
Accepted Manuscript (AM) of Vullnetari, J. and King, R. (2011) 'Washing men's feet': Gender, care and migration in Albania during and after communism. Gender and Development 19(1): 39-51 [DOI:

10.1080/13552074.2011.554020][accepted November 2010; first published online 17 March 2011].

need to repay the social 'debt' incurred by her friends and neighbours' mourning her fatherin-law's death:

... the household has many requirements, my kin and my husband's kin both need attention. I will meet this [obligation], I will need to clear it [the debt] because it's on my head, on my back [as a burden]. Whoever came to console me when my father-in-law died, I have it all, I have noted everything [often notebooks are passed from one generation to another], who came, who brought what, where my debt is... So I know what I need to do, and if I have a certain event like this, I take care of it [Flutur, 47].

Migration from the village has both challenged and reinforced such traditional customs and norms. On the one hand, migrant remittances enable families to continue attending events, and to contribute higher sums to service them. On the other hand, as people live far away in other countries and continents - they visit less often, which can result in alienation from such norms.

\section{Gender relations, remitting and decision-making}

We can see that the processes of migration and remitting money are strongly shaped by gender. On the other hand, the impacts of what Peggy Levitt (1998) calls social remittances, in other words 'the ideas, behaviors, identities and social capital that flow from receiving- to sending-country communities' (p. 926), are felt strongly in relation to gender.(3)

\section{Gender shaping migration and remittances}

Gender relations are embedded in specific social and cultural contexts of origin and host communities. Patriarchal gender relations in Albania translate into male-led migration, as we saw earlier, which in turn also conditions remitting patterns, placing men as principal senders, while women's role is consigned to that of receivers. This is not to say that women do not remit at all, or that they are passive receivers. Indeed, we saw that complex configurations of remitting patterns are much more common than expected. 
Accepted Manuscript (AM) of Vullnetari, J. and King, R. (2011) 'Washing men's feet': Gender, care and migration in Albania during and after communism. Gender and Development 19(1): 39-51 [DOI:

10.1080/13552074.2011.554020][accepted November 2010; first published online 17 March 2011].

In addition, women may deploy other types of remittances such as in-kind transfers to make up for sending less money. Migrant women most commonly send home clothes, furniture, foodstuffs and items such as medicines, television sets, fridges or washing machines. These goods are sent home by married women in particular. In her study of gender, migration and kinship ties among transnational households in rural central Albania, Erin Smith (2009) likewise noted how sending or bringing back such material goods provided an avenue for married women to make up for the asymmetric remitting patterns whereby men remit more money than women.

When it comes to remittance uses, there is a tendency for married women to think in terms of investing to upgrade and furnish the family's home, and for their male counterparts to start or expand the family's business - usually an agricultural enterprise.

\section{Migration and remittances shaping gender relations}

Working outside the home in paid employment is not new to Albanian women; during communism, they participated alongside men in various sectors of the economy. What has changed now, in this era of widespread male migration, is that the women left at home are shouldering a wider range of activities on their own, while their husbands work abroad. This is happening in a so-called post-communist 'transition' environment, where kinship networks do not provide the same support as before, while statutory services such as childcare and healthcare are severely starved of public investments, especially in rural areas. While feeling empowered because they manage money, the women in our research also reported feeling burdened, especially when it comes to looking after children's upbringing and schooling. Donika, 37, explained:

If he [her husband] is here [in Albania] it goes without saying that he has that weight [of decision-making], he takes that upon himself from the day he arrives. I feel like a weight has been lifted off my shoulders. When he is not here, I am on my own... 
Accepted Manuscript (AM) of Vullnetari, J. and King, R. (2011) 'Washing men's feet': Gender, care and migration in Albania during and after communism. Gender and Development 19(1): 39-51 [DOI:

10.1080/13552074.2011.554020][accepted November 2010; first published online 17 March 2011].

On the other hand, remittances have improved women's work and living environments they can now use a washing machine instead of washing clothes by hand, have an electric cooker instead of a wood-stove or oil-fed cooking ring, and can buy better clothes, furniture, or enjoy some free time. Yet, they are overwhelmingly the ones who continue to perform all these household 'duties'.

In our study, we found that women's and men's expectations vis-à-vis the gendered roles which they adopt within the transnational family have not changed much. Men are expected to continue to take on the role of principal breadwinner, going out and earning money, whilst women's principal role continues to be to look after the children, the household and fragile elderly parents. If women earn an income of their own, this is almost always considered as supplementary to that of their husband. This is the case even when women's earnings are more stable than their husbands', in that the jobs they have - often caring for the elderly or children in Greek families - provide a predictable and continuous income stream.

In our view, our findings suggest that, if anything, the patterns of migration and remitting which we saw earlier have reinforced such traditional gender roles in certain cases. For example, when the husband's remittances to his wife in the village are sufficient to ensure a satisfactory standard of living, the wife may withdraw from working outside the home altogether; she will only focus on household keeping and the children instead. In such cases, the husband is seen as a successful (migrant) man who has assured such affluence to his family so that his wife can afford 'the luxury' of 'staying at home'. This needs to be understood in the context of a post-communist rural society, where women's options for paid employment are very limited. Moreover, the kinds of jobs available to them are generally in subsistence agriculture locally, or in garment factories in nearby towns where rural residents have limited transport links. Furthermore, 'staying at home' can be seen as an exercise of choice and freedom - albeit one arranged by power between men and women - in contrast to older women's experiences under communism who did not have this choice but were compelled by the authorities to participate in outdoor labour. Another reason why this may be the case is that the 'social remittances' (Levitt 1998) - the ideas that are brought 
Accepted Manuscript (AM) of Vullnetari, J. and King, R. (2011) 'Washing men's feet': Gender, care and migration in Albania during and after communism. Gender and Development 19(1): 39-51 [DOI:

10.1080/13552074.2011.554020][accepted November 2010; first published online 17 March 2011].

to Albania by migrants from the society which is hosting them - may not be very progressive in relation to gender norms. Greece is itself quite patriarchal when it comes to gendered attitudes to 'breadwinner' roles, and gender relations within the household.

However, some change to gender roles and the norms which accompany them has taken place, more strongly noted in migrants' households in Greece. Especially important in shaping the new roles have been the practicalities of everyday life as a migrant single man, or working couple. Some of these have affected rural areas of origin too, albeit to a lesser degree, as the two examples below illustrate.

Refat, aged 42, who is a migrant in Thessaloniki, observed:

Of course things have changed. Would you see me in Albania looking after the baby? No way! When I would come to visit [between spells of working in Greece] and stay for about ten days, my wife would ask me for instance: can you look after the baby as I need to go downstairs to do something. I would go out instead and leave. Whereas here [since family reunification in Greece] my wife is at work, I have to look after our daughters... When I come home from work at three or four o'clock... because they are young. There is no other way... This is the change.

Elona, aged 45, wife of a seasonal migrant to Greece, said:

When I first came here [to her husband's household in Albania] he would't touch any chores. Because he goes to Greece now, they live there for months and have to wash, cook, of course this is normal, they have to eat. So he is used to these things now and when he comes home he helps me when I need help. If I ask him to wash a dish, he understands, he does it, it's not a problem. But I don't let him [do the house chores], I can't allow it [her self-esteem as a woman would be damaged]. But when I have too much work I do ask him. 
Accepted Manuscript (AM) of Vullnetari, J. and King, R. (2011) 'Washing men's feet': Gender, care and migration in Albania during and after communism. Gender and Development 19(1): 39-51 [DOI:

10.1080/13552074.2011.554020][accepted November 2010; first published online 17 March 2011].

\section{Conclusion}

Gender relations have a strong role in shaping migration and related processes such as remittances. Therefore, in order to understand the effects of the latter on development, it is imperative that studies of remittances pay due attention to gender relations and processes. When this takes place, it is not enough to ask whether women are better remitters than men. That question will provide an answer which is barely useful to policy-makers and practitioners who are looking to enhance the capabilities of women - and men - to improve their quality of life. Instead, research needs to tease out the complexity of inter-relations between gender and remittances - financial and non-monetary - as embedded within the specific social and cultural contexts across which transnational migrant households operate. Some guidelines, based on previous work by other researchers, are provided at the beginning of this paper. We hope that other critical voices will enrich this framework and apply it in practical projects which enable migrants and their families to enhance their capabilities.

Julie Vullnetari is Research Fellow at the Sussex Centre for Migration Research, School of Global Studies

Russell King is Professor of Geography and Director of the Sussex Centre for Migration Research, School of Global Studies

University of Sussex, Falmer, Brighton, BN1 9JS, UK

E-mail: J.Vullnetari@sussex.ac.uk; R.King@sussex.ac.uk

\section{Endnotes}

(1) A pseudonym, like all the other informants' names used in this paper.

(2) For an overview of these earlier migrations see King and Vullnetari (2003).

(3) Although these refer to a range of non-monetary transfers, including ideas related to political systems and democracy, we only focus here on gender relations. For a more comprehensive analysis of the various non-monetary remittances see our discussion in Vullnetari and King (2011). 
Accepted Manuscript (AM) of Vullnetari, J. and King, R. (2011) 'Washing men's feet': Gender, care and migration in Albania during and after communism. Gender and Development 19(1): 39-51 [DOI:

10.1080/13552074.2011.554020][accepted November 2010; first published online 17 March 2011].

\section{References}

de Haas, H. (2009) 'Mobility and Human Development', New York: United Nations Development Programme, Human Development Report Office, Human Development Research Paper 1

Goldring, L. (2003) 'Re-thinking Remittances: Social and Political Dimensions of Individual and Collective Remittances', Toronto: York University, Center for Research on Latin America and the Caribbean (CERLAC) Working Paper

King, R., M. Dalipaj and N. Mai (2006) 'Gendering migration and remittances: evidence from London and Northern Albania', Population, Space and Place 12(6): 409-34

King, R. and J. Vullnetari (2003) 'Migration and Development in Albania', Brighton: University of Sussex, Development Research Centre on Migration, Globalisation and Poverty, Working Paper C5

King, R. and J. Vullnetari (2010) 'Gender and Remittances in Albania: Or Why "Are Women Better Remitters than Men?" is not the Right Question', Brighton: Sussex Centre for Migration Research, Working Paper 58

Levitt, P. (1998) 'Social remittances: migration driven local-level forms of cultural diffusion', International Migration Review 32(4): 926-48

Mahler, S.J. and P. Pessar (2001) 'Gendered geographies of power: analyzing gender across transnational spaces', Identities 7(4): 441-59

Marcus, G. (1995) 'Ethnography in/of the World System, the emergence of multi-sited ethnography', Annual Review of Anthropology 24: 95-117

Pessar, P. and S.J. Mahler (2003) 'Transnational migration: bringing gender in', International Migration Review 37(3): 812-46 
Accepted Manuscript (AM) of Vullnetari, J. and King, R. (2011) 'Washing men's feet': Gender, care and migration in Albania during and after communism. Gender and Development 19(1): 39-51 [DOI:

10.1080/13552074.2011.554020][accepted November 2010; first published online 17 March 2011].

Sen, A. (1999) Development as Freedom, New York: Anchor Books

Smith, E. (2009) "'Gap-fillers" or "clan-destroyers"? Transnational female solidarity towards kin in the region of Fier', Southeast European and Black Sea Studies 9(4): 555-73

UNDP (2009) 'Human Development Report 2009. Overcoming Barriers: Human Mobility and Development', New York: United Nations Development Programme

Vullnetari, J. and R. King (2011) Remittances, Gender and Development: Albania's Society and Economy in Transition, London: I.B. Tauris (in press) 